\title{
SPATIAL VARIABILITY OF CHANNEL CHANGES IN A MEDITERRANEAN EPHEMERAL STREAM IN THE LAST SIX DECADES (1946-2006)
}

\author{
C. SANCHIS-IBOR ${ }^{1}$, F. SEGURA-BELTRÁN ${ }^{2 *}$ \\ ${ }^{1}$ Centro Valenciano de Estudios del Riego, Universitat Politècnica de València, 46022 València, Spain \\ ${ }^{2}$ Departament de Geografia, Universitat de València, Avda./Blasco Ibáñez 28, 46010 València, Spain.
}

\begin{abstract}
An analysis of morphological changes during the last six decades is presented for the Rambla de Cervera, a Mediterranean ephemeral stream located in the eastern sector of the Iberian Mountain Range. The studied channel (16.5 km) has two contrasted sectors: a horst confined sector $(5.5 \mathrm{~km})$ and a graben sector $(11 \mathrm{~km})$. Channel changes were analysed through the analysis of aerial photographs, with geographical information systems (GIS) and comparison of topographic surveys made with a GPS-RTK. Between 1946 and 2006 the Rambla de Cervera, underwent channel adjustments comparable to those observed in other Mediterranean rivers. The gravel channel markedly narrowed, losing width (68.5\%) and channel surface area (45.7\%), and incision processes occurred along the entire study reach at an average depth of $3.5 \mathrm{~m}$. The progressive reduction of discharge and sediment supply due to land use changes, gravel mining and hydroclimatic variability has been considered responsible for these changes. However, these morphological changes exhibit an interesting temporal variability, with a maximum decrease of the gravel channel in the period 1946-1956 and another clear narrowing stage between 1977 and 1991, whereas incision mainly progressed after 1977. In addition, a contrasted behavior between the graben and horst sectors has been observed and analyzed. The horst sector underwent a constant and continuous trend, whereas the graben sector had more intense changes and two stages with significant reverse trajectories. The differential behavior of the graben and horst sectors was caused by the different responses generated by the overlapping of the lack of sediment supply, the timing and intensity of flood events and the particular hydraulic conditions of both sectors. The hydraulic geometry of the different river sections conditioned the effectiveness of flood events, influencing on the existence or absence offloodplain destructive trajectories and on the stability of fluvial forms.
\end{abstract}

Variabilidad espacial de los cambios de cauce en una rambla mediterránea en las seis últimas décadas (1946-2006)

RESUMEN. En el presente trabajo se realiza un análisis de los cambios morfológicos ocurridos en la cuenca y el cauce de la Rambla de Cervera, situada en la parte 
oriental del Sistema Ibérico. El tramo de estudio $(16.5 \mathrm{~km})$ discurre primero confinado en un horst $(5.5 \mathrm{~km})$, y posteriormente en un graben $(11 \mathrm{~km})$. Los cambios en el cauce han sido estudiados y cartografiados a partir de la fotografía aérea y levantamientos topográficos realizados con un GPS-RTK, para ser después analizados mediante SIG. Entre 1946 y 2006 la rambla redujo la anchura de su cauce en un $68.5 \%$, la superficie del canal de gravas se redujo en un $47.5 \%$ y se registró una incisión media de $3.5 \mathrm{~m}$. Estos cambios, al igual que en otros ríos mediterráneos, se han atribuido a la progresiva disminución del caudal y del sedimento disponible a lo largo del siglo XX, producidos fundamentalmente por los cambios de usos del suelo, la extracción de áridos y la variabilidad hidroclimática. Los cambios observados presentan una interesante variabilidad temporal, con una reducción máxima del canal de gravas entre 1946 y 1956 y un segundo período entre 1977-1991, mientras que la incisión se aceleró a partir de 1977. El trabajo se centra en el análisis del comportamiento diferencial entre los sectores del horst y el graben del tramo fluvial. El primero muestra una tendencia evolutiva más regular, mientras que el segundo sector presenta periodos de inversión de tendencias. En el presente trabajo se analizan esas diferencias y se establece un modelo explicativo sobre los factores locales que influyen en este contrastado comportamiento. Los cambios en la geometría hidráulica provocados por el confinamiento y por la incisión, así como la variabilidad hidrológica espacio-temporal son responsables de las diferencias entre ambos sectores. Así, el cambio de un sector confinado a otro no confinado y el incremento del radio hidráulico influyen en el comportamiento de las crecidas a lo largo del período.

Key words: channel forms, floods, incision, land use change, horst, graben.

Palabras clave: crecidas, formas del cauce, usos del suelo, incisión, horst, graben .

Received 11 December 2013

Accepted 11 February 2014

*Corresponding author: Departament de Geografia, Universitat de València, Avda./Blasco Ibáñez 28, 46010 València, Spain.E-mail: francisca.segura@uv.es

\section{Introduction}

Over the last two centuries, continuous adjustments have taken place in the Mediterranean fluvial systems, as a result of the fluctuations of flow and sediment supply. Climatic changes and human activities have been associated with these adjustments, influencing erosion and deposition of sediment. Much discussion has focused on the effect of human activities and its relative importance compared with climatic impacts in fluvial systems, and several studies have analyzed the links between morphological changes and anthropogenic activity in the region (Hooke, 2006; Gurnell et al., 2009).

Channel adjustments in recent decades, in particular incision, narrowing and morphologic changes have been documented and attributed to the decrease in flow and sediment supply. Causal interpretation has often been addressed through retrospective 
analyses of anthropogenic actions such as dam construction, reforestation, torrent control works, or river channelization (Bravard et al., 1997; Rinaldi, 2003; Surian and Rinaldi, 2003; Surian and Cisotto, 2007; García-Ruíz and Lana-Renault, 2011). Gravel extraction has also had a profound impact on rivers around the world (Kondolf et al., 2002; Liébault and Piégay, 2002; Surian and Rinaldi, 2003; Piégay et al., 2004; Rinaldi et al., 2005; Wishart et al., 2008; Surian et al., 2009).

Researchers have attempted to establish a chronology of recent historical changes in river morphology in the Mediterranean region of Europe. In French rivers, channel narrowing in the first half of the twentieth century has been associated with decreased discharge and sediment supply at the end of the Little Ice Age. In contrast, channel reduction in the second half of the twentieth century is considered a human-induced fluvial adjustment (Bravard et al., 1997; Liébault and Piégay, 2002; Arnaud-Fassetta, 2003; Liébault et al., 2005). In Italy, Surian et al. (2009) detected small width changes during the nineteenth century, but with no significant trend. From the end of the nineteenth century to the 1980s/1990s, channel narrowing and incision occurred, with particular intensity after the 1950s. Finally, during the last two decades, widening sedimentation and bed-level stabilization predominate, although some river reaches are still narrowing. In Spanish rivers, several studies have shown an increase in flood frequency in the Mediterranean region over the past centuries, with a particular rise in the eighteenth and nineteenth centuries, which they attribute primarily to climatic fluctuations during or at the end of the Little Ice Age (e.g. Barriendos and Rodrigo, 2006; Benito et al., 2008; Glaser et al., 2010). López-Bermúdez et al. (2002) examined the occurrence of floods in ephemeral streams at the beginning of the twentieth century in the Mediterranean region, which they attribute primarily to deforestation. Additionally, important changes occurred in the second part of the twentieth century dealing mainly with land use changes (Beguería et al., 2006; LópezMoreno et al., 2006; García-Ruíz, 2010; Gallart et al., 2011) and torrent control works (Boix-Fayos et al., 2007). The impact of gravel mining was particularly severe in the period 1950-1980, and it is a major contributor to river incision in Spanish rivers (Batalla, 2003; Rovira et al., 2005, Martín-Vide et al., 2010).

Mean incision values have been estimated in the Italian perennial rivers (3-4 m) (Surian and Rinaldi, 2003; Surian and Cisotto, 2007; Rinaldi et al., 2009; Surian et al., 2009; Preciso et al., 2012; Gurnell et al., 2012), French rivers (1-5 m) (Bravard et al., 1997; Liébault and Piégay, 2002; Arnaud-Fassetta, 2003; Liébault et al., 2005), and Spanish rivers (0.6-5.5 m) (Boix-Fayos et al., 2007; Martín-Vide et al., 2010; SeguraBeltrán and Sanchis-Ibor, 2013). These values range in the same order of magnitude as those observed in ephemeral streams in the USA (Rinaldi et al., 2005; Cadol et al., 2011) and Israel (Rozin and Schick, 1996). The time sequence is in most cases similar: incision is detected in the 1940s and increases later, especially in those rivers where gravel mining progresses (Rinaldi et al., 2005).

However in Mediterranean Europe, most of the research has been developed in perennial rivers where the impact of flow on channel morphology is permanent. Less is known about river adjustments in ephemeral streams, where there are long periods of stability and a higher dependence of morphological changes on extreme or flash-flood 
events (Segura-Beltrán and Sanchis-Ibor, 2013). Moreover, scarce attention has been paid to the spatial variability of these changes, which occur over long time scales, vary as a function of distance from sediment sources and depend on local channel characteristics.

Between 1946 and 2006 the Rambla de Cervera, an ephemeral stream in the north of Valencia Region (Spain) (Fig. 1), underwent channel adjustments comparable to those observed in other Mediterranean rivers. The gravel channel markedly narrowed, losing width $(68.5 \%)$ and channel surface area $(45.7 \%)$, and incision processes occurred along the entire study reach at an average depth of $3.5 \mathrm{~m}$. These morphological changes exhibit an interesting temporal variability, with a maximum decrease of the gravel channel in the period 1946-1956 and another clear narrowing stage between 1977 and 1991, whereas
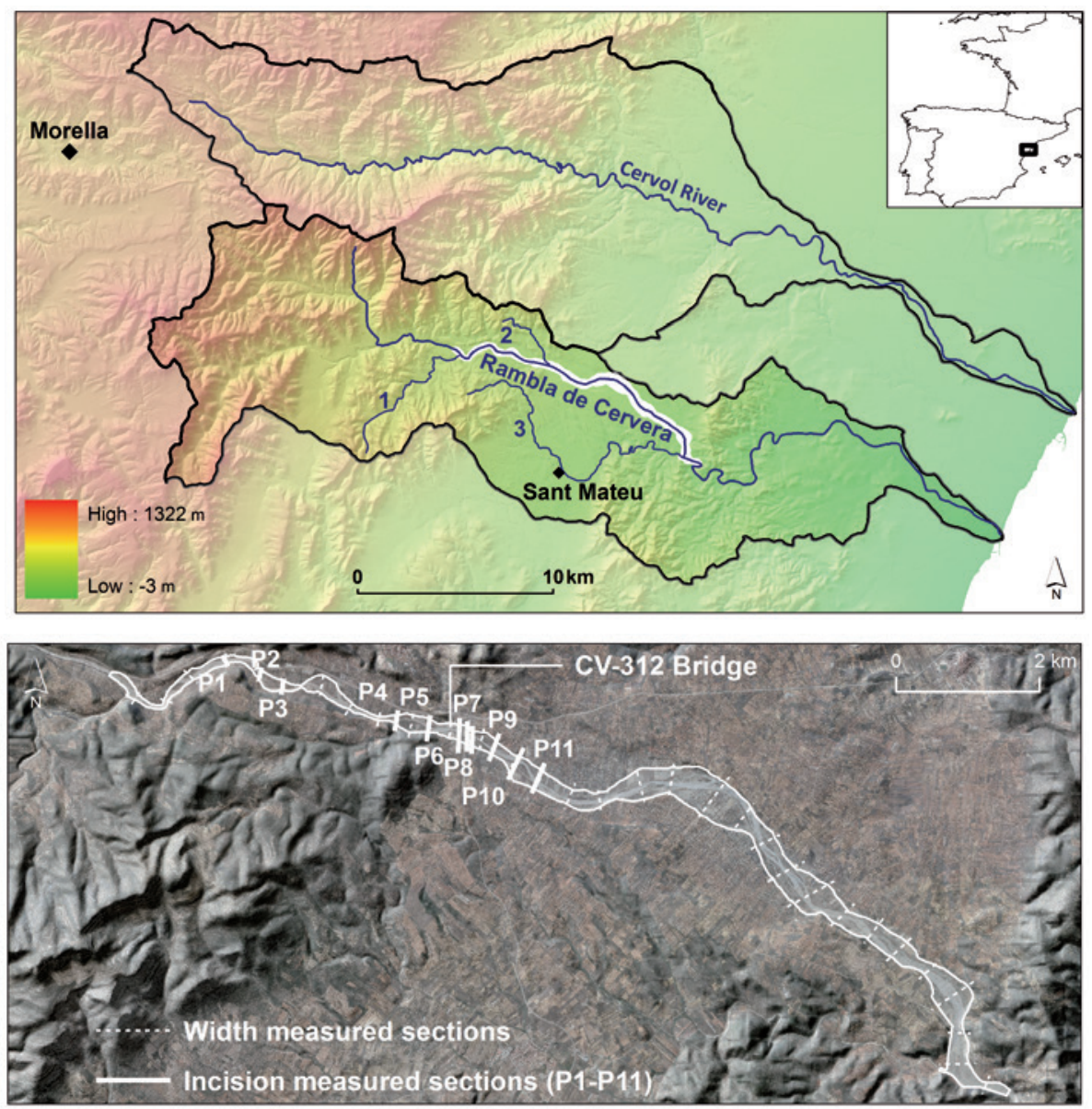

Figure 1. Sketch of location: (Upper panel, A) Rambla de Cervera and Cervol River basins and weather stations, with the study reach in white. 1. Barranc del Molinar, 2. Barranc de la Font and 3. Barranc de Mateu Sant; (Lower panel, B) Rambla de Cervera study reach and sections where incision and width were measured. The channel width (the sum of the single branches widths) has been measured every $500 \mathrm{~m}$. Eleven sections were selected in order to measure incision processes. The hillshade map shows the contrast between the horst and the graben area. 
incision mainly progressed after 1977. Natural and human-induced factors producing contradictory effects have been considered responsible for these changes in the Rambla de Cervera (Segura-Beltrán and Sanchis-Ibor, 2013). The elaboration of a conceptual cause-effect framework has defined the major influencing factors and the timing of processes affecting recent historical changes in the Rambla de Cervera (Fig. 2). The driving factors of these changes are decreasing sediment load, caused by revegetation processes and gravel-mining, and the spatio-temporal variability of floods.

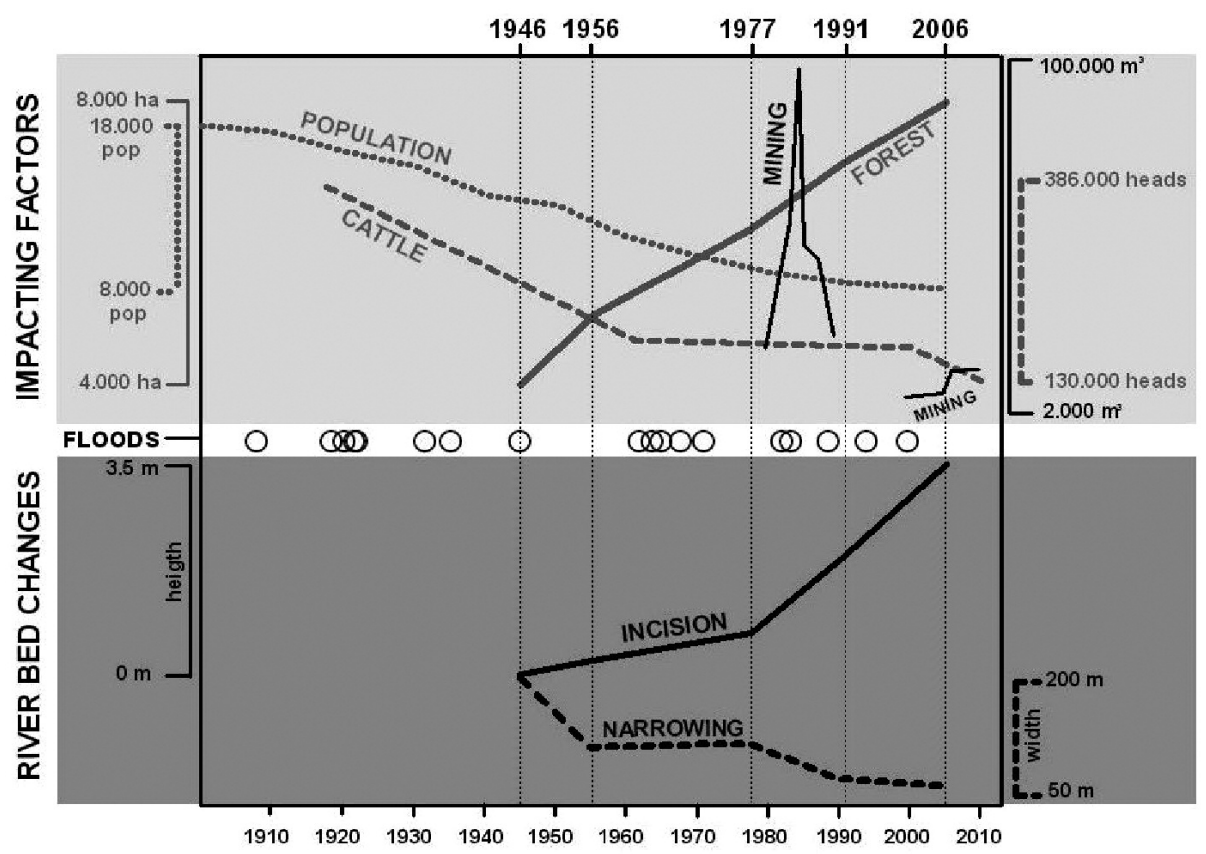

Figure 2. Trends of river adjustments, main human disturbance factors, and natural reforestation causing bed river changes in the Rambla de Cervera (Segura-Beltrán and Sanchis-Ibor, 2013).

However, previous works (Segura-Beltrán and Sanchis-Ibor, 2013) have shown a contrasted behavior between the graben and horst sectors, which has not been previously analyzed. For this reason, the present work aims to study these differences, searching for an explanatory model of the local factors that contributed to these changes in both sectors. This article focuses on the following questions: a) the analysis of the spatial distribution channel changes in the Rambla de Cervera between 1946 and 2006; b) the causal explanation of these changes considering the particularities of ephemeral rivers; c) the influence of the hydraulic geometry on the river channel forms.

\section{Regional setting}

The basin of the Rambla de Cervera $\left(339.6 \mathrm{~km}^{2}\right)$ is located in the Oriental Sector of the Iberian Mountain Range (Fig. 1A). The mountain range was folded during the paroxysmal compressive phase in the Oligocene, when anticlinal and synclinal 
structures with a NW-SE direction were formed. Later, at the end of the Tertiary and the beginning of the Quaternary, two distensive phases generated horsts and grabens, transverse to the Iberian Mountain Range direction.

The stream rises at $1160 \mathrm{~m}$. a.s.l. and flows $44 \mathrm{~km}$ in an easterly direction to the Mediterranean Sea, crossing horsts and grabens perpendicularly. The studied channel reach is $16.5 \mathrm{~km}$ long, $5.5 \mathrm{~km}$ in the confined sector and $11 \mathrm{~km}$ in the graben part (Fig. 1B). In the horst area, the channel is constricted and the river adopts a wandering pattern; in the graben, lateral shift is important, and the river has a multithread braided pattern.

The headwaters are composed of Mesozoic calcareous rocks, mainly limestone, dolomies and several marls. Limestones and dolomies are hardly karstified and very permeable. Local calcareous aquifers, thick but very deep, favor the formation of ephemeral streams. In the graben, the rambla formed an important alluvial fan during the Oligocene. Several Quaternary terraces can be located along the studied reach, especially in the graben part. The river has a slope of $1.4 \%$ and the channel bed is mainly composed of cobbles and gravels, with an average size of $25.8 \mathrm{~mm}$. Most of the river bed is armoured (Segura, 1990).

The mean annual rainfall ranges between $700 \mathrm{~mm}$ and $480 \mathrm{~mm}$, decreasing from west to east. The maximum monthly rainfall typically occurs in autumn and spring, with a summer minimum in July. The river only flows after heavy rains. Runoff appears from two to four times a year on average; and it is usually discontinuous along the channel. The combination of the basin physical characteristics (permeable rock, thin soils, steep slopes, and sparse vegetation) and intense, heavy, and irregularly distributed rainfall generates flash floods. Hydrographs have sharp rising limbs and short lag times (Segura, 1990; Camarasa-Belmonte and Segura-Beltrán, 2001).

The headwaters area encompasses the basin located upstream of the highest point of the Rambla de Cervera study reach. It is $114.8 \mathrm{~km}^{2}$ if we consider the basin of Catinells ravine, which flows into the Rambla Cervera just at the beginning of the horst sector. The direct tributaries of the study reach are few and very short: the ravine of El Molinar $\left(6.8 \mathrm{~km}^{2}\right)$ in the horst sector, and the Barranc de la Font $\left(3.6 \mathrm{~km}^{2}\right)$, at the beginning of the graben sector. The last one is the largest, the ravine of Sant Mateu $\left(67.1 \mathrm{~km}^{2}\right)$, but flows just at the end of the study reach and hence has not significant impact as a sediment source for this study. The Rambla the Cervera and these four tributaries have been ungauged during the study period.

\section{Methods}

\subsection{Changes in river planform}

In order to investigate recent changes in the study reach, we used aerial photographs and orthophotos from different dates (Table 1). The photographs were scanned at a resolution of 400 dpi to obtain average pixel dimensions of $\sim 1 \mathrm{~m}$. They were georeferenced to orthophotos using ArcGIS ${ }^{\mathrm{TM}}$ version 9.3 (ESRI, Redlands, CA, 
2009). Ground control points (GCPs) were selected from the image (for $~ 10-12$ points along the river corridor) to georectify the images through a second order polynomial. We adopted bilinear interpolation resampling and admitted a maximum acceptable root mean square error (RMS) of $<5$ pixels. Completely correcting the georectifying error between adjacent photos was impossible, especially in the older photographs. According to Mount et al. (2003), we estimated errors for channel width measurements based on the aerial photograph sources. Image distortion errors $(\theta)$ ranged between 3 (1946) and $6.4 \mathrm{~m}$ (1956), whereas the location errors (pR) ranged between 1.8 (1977) and $3.5 \mathrm{~m}$ (1956) and the mean width error $\left(\mathrm{e}_{\mathrm{w}}\right)$ was $10.6 \mathrm{~m}$.

Table 1. Images analysed in the present study.

\begin{tabular}{|l|l|l|l|l|l|}
\hline Year & Type & Scale & Agency & $\begin{array}{c}\text { Pixel } \\
\text { resampling } \\
(\mathbf{m})\end{array}$ & $\begin{array}{c}\text { Film } \\
\text { and color }\end{array}$ \\
\hline 1946 & Aerial photograph & $1 / 43000$ & Ministry of Defense (CECAF) & 1 & $\begin{array}{l}\text { Panchromatic } \\
\text { Black-and-white }\end{array}$ \\
\hline 1956 & Aerial photograph & $1 / 33333$ & Ministry of Defense (CECAF) & 1.15 & $\begin{array}{l}\text { Panchromatic } \\
\text { Black-and-white }\end{array}$ \\
\hline 1977 & Aerial photograph & $1 / 18000$ & Ministry of Agriculture (IRYDA) & 0.60 & $\begin{array}{l}\text { Panchromatic } \\
\text { Black-and-white }\end{array}$ \\
\hline 1991 & Aerial photograph & $1 / 25000$ & Valencian Institute of Cartography (ICV) & 0.85 & $\begin{array}{l}\text { Panchromatic } \\
\text { Black-and-white }\end{array}$ \\
\hline 2006 & Orthophoto & $1 / 5000$ & Valencian Institute of Cartography (ICV) & 0.50 & Digital color \\
\hline
\end{tabular}

The images were then interpreted to identify changes in river corridor morphology. The margins of each form were manually digitized; and an attribute table was created for the resulting polygons. The channel forms were classified following a modification of the conceptual model of Gurnell et al. (2001) and Zanoni et al. (2008). We distinguished between: (i) gravel channels, unvegetated branches of the river bed, frequently affected by flow; (ii) incipient islands, gravel or cobble patches covered by less than the $20 \%$ scattered bushes and sparse grass cover; (iii) established islands, covered by more than the $20 \%$ scattered bushes or trees and completely covered by a dense grass layer or occupied by crops (olive trees or vines); and (iv) dissected floodplain islands, the remaining parts of the floodplain incorporated to the active corridor by chute cutoff processes.

These floodplain islands differ from those established by the alignment of the crops and plots on either side of the chute cutoff, and they can be identified by comparing subsequent or previous photographs. Although underrepresented, the chute channels have been separated from the gravel channel category because they indicate processes of floodplain dissection. The outer limit of the active corridor was defined by the boundary between areas of gravel and any remaining, extended vegetated surface that had not been classified as island at any period (Zanoni et al., 2008). 


\subsection{Channel incision and channel width measurement assessed by topographic survey and aerial photographs}

Channel width is considered in this work the result of measuring the total unvegetated width, that is, the sum of the single channel branches widths, plus the unvegetated gravel bars (Bertoldi et al., 2009; Michalková et al., 2010). Channel width was measured on the aerial photographs every $500 \mathrm{~m}$ along the entire study reach $(16.5 \mathrm{~km})$.

The incision was measured indirectly from a survey conducted in 2011 on the first $10 \mathrm{~km}$ of the study area. We assumed that incision has not increased since 2006 because no significant flow event occurred during the last six years. The measurements were made using GPS-RTK (accuracy of $15 \mathrm{~cm}$ ), and they covered an area of $314400 \mathrm{~m}^{2}$ with 9242 points $\left(0.029\right.$ points $\left.\mathrm{m}^{-2}\right)$. A DEM of $1-\mathrm{m}$ resolution generated from survey data was used to make cross sections.

The active corridor of 1946, 1956, 1977, 1991, and 2006 was used to define the external limit of channel courses during the last 60 years. Using ArcGis spatial analyst tools, we calculated numerous profiles, selecting 11 of them considered optimal for incision estimation (Fig. 1). The distance between them is variable and different for those sections where width was calculated. The necessary conditions for selection were: (i) sections where the corridor has narrowed in all the periods; (ii) clear channel boundaries; and (iii) boundaries coincident with microterraces, identified through photointerpretation and field work. The incision was calculated in each section measuring the height of the boundary channel each year (1946, 1956, 1977, 1999 and 2006). Stereoscopic analysis and fieldwork contributed to corroborate the information provided by cross section analysis.

\subsection{Natural and human-induced influencing factors}

\subsubsection{Rainfall and flood series}

The most relevant floods of the Cervol River and Rambla de Cervera have been reconstructed consulting archives and newspapers, rainfall data, and stream flow gauging data of the Cervol River. This river, adjacent to the Rambla de Cervera, was gauged between 1911-1929. In addition to this, we have considered rainfall series from four weather stations representing different climatic conditions of this basin (Table 2). Climatic series were studied in order to identify the whole of total rainfall events $>65 \mathrm{~mm}$, assuming that this threshold establishes the minimum rainfall for runoff production in the region (Segura, 1990; Camarasa-Belmonte and Segura-Beltrán, 2001).

Table 2. Rainfall series characteristics in the weather stations of the study area.

\begin{tabular}{|l|c|c|c|c|c|c|c|c|}
\hline Weather station & Period & $\begin{array}{c}\text { Mean annual } \\
\text { rainfall } \\
(\mathbf{m m})\end{array}$ & $\begin{array}{c}\text { Total } \\
\text { years }\end{array}$ & Complete & Incomplete & Gaps & X-UTM & Y-UTM \\
\hline Morella & $1920-2010$ & 566 & 91 & 53 & 13 & 25 & 745317 & 4500696 \\
\hline Morella-La Vella & $1945-2004$ & 584.11 & 60 & 33 & 9 & 18 & 741738 & 4502957 \\
\hline Sant Mateu & $1943-1962$ & 601 & 21 & 18 & 3 & & 769608 & 4484861 \\
\hline Sant Mateu HS & $1971-2001$ & 692 & 32 & 27 & 5 & & 769344 & 4483678 \\
\hline
\end{tabular}




\subsubsection{Land use changes}

The land uses in the Rambla de Cervera basin between 1946 and 2006 were mapped. Seven land use types were selected to classify the study area: (i) urban areas; (ii) forested areas ( $>50 \%$ of forest strata coverage); (iii) bush or shrub areas; (iv) rainfed annual crops; (v) rainfed cultivated trees; (vi) sparsely vegetated areas, also including small bare rock patches and recent burnt areas; and (vii) river beds. The basin area affecting the horst and graben sectors was analyzed separately.

\subsubsection{Gravel mining data}

Gravel mining data are difficult to obtain because the Spanish administration did not register continuous and standardized information on mining concessions, and they did not control extractions rigorously. Extractions started in 1972 in the study reach, but the available public data cover a shorter period. We obtained different information from the administration: (i) annual data between 1980 and 1988 (Pardo, 1991); (ii) total data of the periods 2000-2005 and 2006-2007 (information obtained from the Confederación Hidrográfica del Júcar); and (iii) no data between 1972 and 1979 or between 1989 and 1999. These data reflect the amount of gravel extracted by the two companies working in the whole river, impeding the quantification of the amount extracted in the study area. Photointerpretation and local interviews were conducted for a better understanding of the spatio-temporal distribution gravel mining impact.

\section{Natural and man-induced changes in basin and river conditions}

\subsection{Climatic and hydrological changes}

Rainfall data analysis shows a different behavior between the headwaters (Morella and Morella la Vella) and the study reach (Sant Mateu and Sant Mateu HS) weather stations. From the comparison we have made between the climatic series, we observe that the number of events that exceed the runoff treshold $(>65 \mathrm{~mm})$ is considerably higher in the study reach sector, doubling and tripling the headwaters figures; events $>200 \mathrm{~mm}$ are also more frequent in the graben (Fig. 3).
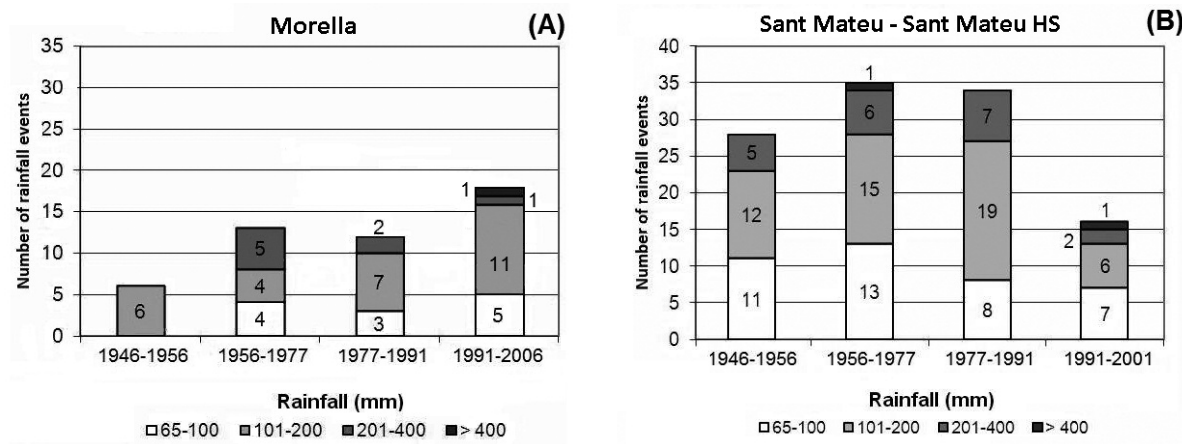

Figure 3. Number of rainfall events $>65 \mathrm{~mm}$ recorded in each of the study periods in Morella (A) and Sant Mateu (B). 
The contrasted magnitude of rainfall in coastal and interior weather stations of this region has been analyzed by several authors. Millán et al. (2005) have identified a different pattern in the period 1950-2000 between those weather stations at a distance higher or lower than $40 \mathrm{~km}$ from the coastline (approximately in mean annual precipitation $400 \mathrm{~m}$ a.s.1.). These authors have found that the interior weather stations have lost $30 \mathrm{~mm}$ during this period, whereas the coastal series remain stable over time. This fact is a consequence of the reduction of the convective and frontal rains, parallel to the increase of cut-off low events causing heavy coastal rains.

The higher frequency of effective rainfall in the study reach sector is compensated by the small size and number of tributaries. Hence, sediment supply is highly dependent on headwaters rainfall. Moreover, large floods only take place when there are heavy rains in both the headwaters and the study reach sectors. Smaller events have only a local impact because of high transmission losses. The lack of gauging data hinders the interpretation of the differential impact of rainfall between the graben and horst sectors. Information on historical and recent flood events permits, at least, to identify a basic sequence of the fluvial activity (Table 3).

Table 3. Rainfall events in the Rambla de Cervera (1945-2006). In bold events $>200 \mathrm{~mm}$ in both horst and graben sectors. nd: no data.

\begin{tabular}{|c|c|c|c|c|}
\hline & Morella & Morella - La Vella & Sant Mateu & Sant Mateu HS \\
\hline $\mathbf{1 4 / 1 1} / \mathbf{1 9 4 5}$ & $\mathbf{2 2 8 . 2}$ & $\mathbf{2 5 2 . 2}$ & $\mathbf{2 3 1 . 8}$ & \\
\hline $18 / 02 / 1948$ & 105.7 & & 214.3 & \\
\hline $\mathbf{1 8 / 1 2} / \mathbf{1 9 4 8}$ & $\mathbf{1 7 0}$ & $\mathbf{2 2 5 . 2}$ & $\mathbf{2 1 9 . 6}$ & \\
\hline $22 / 03 / 1949$ & 105.7 & 40.2 & 198.5 & \\
\hline $23 / 04 / 1951$ & nd & 97 & 230.5 & \\
\hline $08 / 09 / 1951$ & nd & 95.3 & 240.4 & \\
\hline $\mathbf{1 0 / 1 0} / \mathbf{1 9 5 6}$ & nd & $\mathbf{2 7 8 . 1}$ & $\mathbf{2 3 1 . 5}$ & \\
\hline $01 / 10 / 1957$ & nd & nd & 249.4 & \\
\hline $18 / 11 / 1958$ & nd & 46 & 331.4 & \\
\hline $08 / 09 / 1959$ & nd & nd & 203 & \\
\hline $\mathbf{0 9 / 1 0 / 1 9 6 2}$ & $\mathbf{2 0 5 . 9}$ & nd & $\mathbf{4 9 5 . 4}$ & \\
\hline $14 / 12 / 1964$ & 253.9 & nd & & nd \\
\hline $28 / 09 / 1965$ & 289.6 & nd & & nd \\
\hline $21 / 10 / 1967$ & 215.5 & nd & & 24.1 \\
\hline $\mathbf{0 2 / 1 2 / 1 9 7 1}$ & $\mathbf{2 7 0}$ & nd & & 200 \\
\hline $20 / 09 / 1972$ & nd & 83 & & $\mathbf{2 6 0}$ \\
\hline $03 / 02 / 1975$ & nd & 55 & & 224.5 \\
\hline $\mathbf{1 8 / 1 0 / 1 9 8 2}$ & $\mathbf{2 2 4 . 3}$ & $\mathbf{2 4 7 . 4}$ & & $\mathbf{2 0 4}$ \\
\hline $\mathbf{2 8 / 1 0 / 1 9 8 3}$ & $\mathbf{1 8 3}$ & nd & & 199.5 \\
\hline $30 / 09 / 1986$ & 123.5 & nd & & 293.2 \\
\hline $\mathbf{2 9 / 0 3 / 1 9 8 8}$ & $\mathbf{2 5 7 . 4}$ & nd & & 319.5 \\
\hline $31 / 08 / 1989$ & nd & nd & & 224 \\
\hline $08 / 11 / 1989$ & nd & nd & & $\mathbf{3 7 4}$ \\
\hline $26 / 12 / 1989$ & nd & nd & & 215 \\
\hline $28 / 11 / 1991$ & 150.1 & 114.8 & & $\mathbf{4 5 9}$ \\
\hline $\mathbf{2 1 / 0 9 / 1 9 9 4}$ & $\mathbf{2 6 3 . 2}$ & $\mathbf{7 1 . 6}$ & & \\
\hline $29 / 12 / 1996$ & 104.7 & 86.2 & & \\
\hline $23 / 01 / 1998$ & 71.9 & 48.1 & & \\
\hline $\mathbf{2 2 / 1 0 / 2 0 0 0}$ & $\mathbf{5 1 1 . 3}$ & $\mathbf{3 7 7}$ & & \\
\hline & & & & \\
\hline
\end{tabular}




\subsection{Land use changes}

Land use changes follow similar trends in the basin area affecting the graben and horst sectors during the study period. The only significant difference is the major predominance of forests and bush in the headwaters area. In 1946, forest and bush covered the $72 \%$ of the horst basin area. If we consider the graben basin area (the horst basin area plus the drainage area of the direct tributaries to the graben reach), both categories only reached the $53 \%$.

Subsequent depopulation processes and progressive abandonment of extensive mountain exploitation practices (grazing and fuel wood collection) led to the regeneration of local forests in the whole basin, particularly in the headwaters area. Between 1946 and 2006 holmoaks and coniferous forests doubled their surface in both horst and graben drainage areas (Table 4 and Fig. 4). The agricultural surface clearly decreased, resulting in forest and bush increases. Bush presents an apparent stability or slight decrease along the study period, behaving as a transitional stage between the cultivated plots and the forest cover.

Table 4. Land use changes in the horst and graben sectors (\%).

\begin{tabular}{|l|c|c|c|c|}
\hline \multirow{2}{*}{} & \multicolumn{2}{|c|}{ Horst } & \multicolumn{2}{c|}{ Graben } \\
\cline { 2 - 5 } & $\mathbf{1 9 4 6}$ & $\mathbf{2 0 0 6}$ & $\mathbf{1 9 4 6}$ & $\mathbf{2 0 0 6}$ \\
\hline Forest & 22,4 & 44,7 & 15,6 & 33,1 \\
\hline Bush & 50,8 & 44,1 & 37,8 & 39,5 \\
\hline Annual crops & 12 & 2 & 13,2 & 2,6 \\
\hline Tree crops & 10,4 & 6 & 28,9 & 21,7 \\
\hline River channel & 0,6 & 0,3 & 1,4 & 0,8 \\
\hline Sparsely vegetated & 3,7 & 2,8 & 2,9 & 1,9 \\
\hline Urban & 0,1 & 0,2 & 0,2 & 0,4 \\
\hline
\end{tabular}

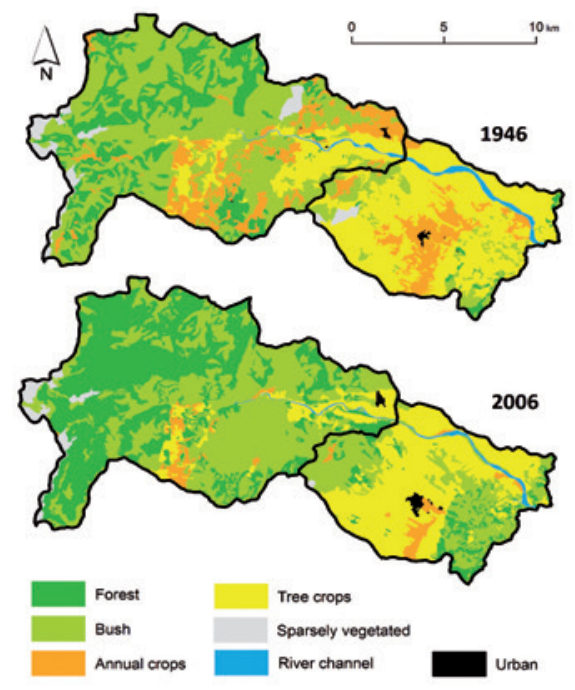

Figure 4. Land use changes in the basin areas affecting the graben and horst sectors. 
Considering that the headwaters area -the basin located upstream of the highest point of the Rambla de Cervera study reach- is the main source of sediments in these basins, the predominance of forest and bush land uses is effectively protecting soil and generating low erosion rates (García-Ruiz and Lana-Renault, 2011). Thus, land use change can be considered a major factor in the decrease of sediment supply along the study period. Despite the common trend, the small differences in forest and bush coverage between the horst and graben sectors, and the distribution of tributary rivers, could indicate that the lack of sediment supply is more relevant in the graben sector.

\subsection{Gravel mining}

In spite of the poor quality of the official data, it is possible to identify the general trend and range of gravel mining in the Rambla de Cervera. As we have stated above, these data are partial and incomplete, but interviews and photointerpretation enable us to corroborate the observed general trend.

Gravel mining started in 1972, and it was particularly intense between 1980 and 1988, when the administration did not establish restrictions, reaching an average of $36600 \mathrm{~m}^{3} \mathrm{y}^{\mathrm{r}}$ (Table 5). During the period 2000-2007, extractions decreased to $3500 \mathrm{~m}^{3} \mathrm{y}^{\mathrm{r}}$, because the administration has intended to reduce the impact of gravel mining on rivers and the companies have started exploiting former agricultural plots in the floodplain. Photointerpretation has shown that the most impacted area was the graben sector.

Table 5. Gravel extracted from the Rambla de Cervera according to the official data.

\begin{tabular}{|c|c|}
\hline Year/period & Volume $\left(\mathbf{m}^{\mathbf{3}}\right)$ \\
\hline $1972-1979$ & - \\
\hline 1980 & 17500 \\
\hline 1981 & 14500 \\
\hline 1982 & 14500 \\
\hline 1983 & 55500 \\
\hline 1984 & 94800 \\
\hline 1985 & 38100 \\
\hline 1986 & 32990 \\
\hline 1987 & 39900 \\
\hline 1988 & 21850 \\
\hline $1989-1999$ & - \\
\hline $2000-2005$ & 10400 \\
\hline $2006-2007$ & $\mathbf{3 5 8 0 4 0}$ \\
\hline Total 1980-2007 & \\
\hline & \\
\hline
\end{tabular}




\section{Results}

\subsection{River incision}

The annual incision ratio in the study reach between 1946 and 2006 is $0.054 \mathrm{~m} \mathrm{yr}^{-1}$, although there are important differences between the four periods. During the two first stages, incision was not intense $\left(0.028 \mathrm{~m} \mathrm{yr}^{-1}\right.$ in $1946-1956$ and $0.021 \mathrm{~m} \mathrm{yr}^{-1}$ in 1956 1977), but increased considerably five years after the start of the gravel mining activity: $0.088 \mathrm{~m} \mathrm{yr}^{-1}$ (1977-1991) and 0.081 $\mathrm{m} \mathrm{yr}^{-1}$ (1991-2011).

Comparing the progress of incision in the study reach with the river mean width, we observe a marked divergence (Fig. 2). On the one hand, incision slowly progressed during the two first stages and increased markedly after 1977; on the other, the channel width decreased significantly in the initial period and, after a stage of readjustment 1956-1977, continued decreasing moderately until 2006. This different behavior is probably reflecting the impact of gravel mining in the incision processes.

The average bed incision of the study reach is $3.5 \mathrm{~m}$, but there is an important spatio-temporal variability. P4 and P7 present the maximum streambed degradation, clearly conditioned by local factors. P4 (distance $=4728 \mathrm{~m}$, incision $=5 \mathrm{~m}$, width section $=57 \mathrm{~m}$ ) is located in the narrowest section of the study reach (Fig. 1B). At this point, the hydraulic radius is high, enhancing incision during floods. P7 (distance = 5078 , incision $=6.44 \mathrm{~m}$, width section $=200 \mathrm{~m}$ ) is located immediately downstream of the CV-312 $250 \mathrm{~m}$ long bridge. Here, incision has been mainly caused by local scour, generating an artificial knickpoint. The concrete footing of the bridge acts as a dyke, stopping headwater erosion and hindering slope regularization. In fact, the lowest values are found at P6 (distance $=5582$, incision $=1.75 \mathrm{~m}$ and width $=215$ ), located upstream of the bridge (Figs. 5 and 6).

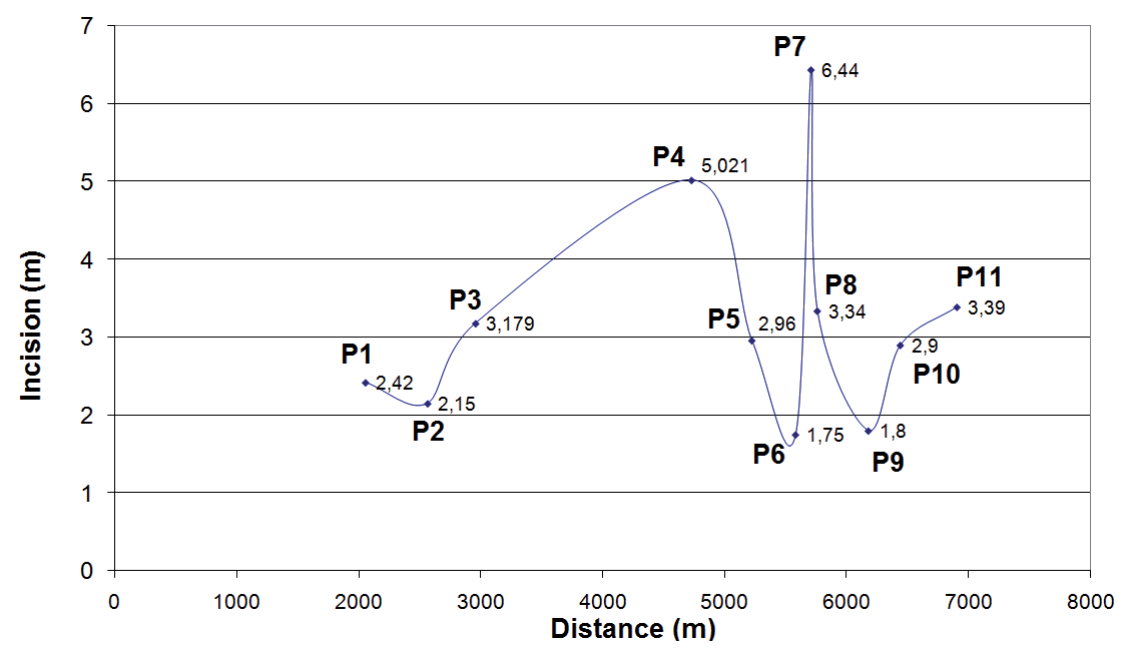

Figure 5. Accumulated incision in the study reach. 


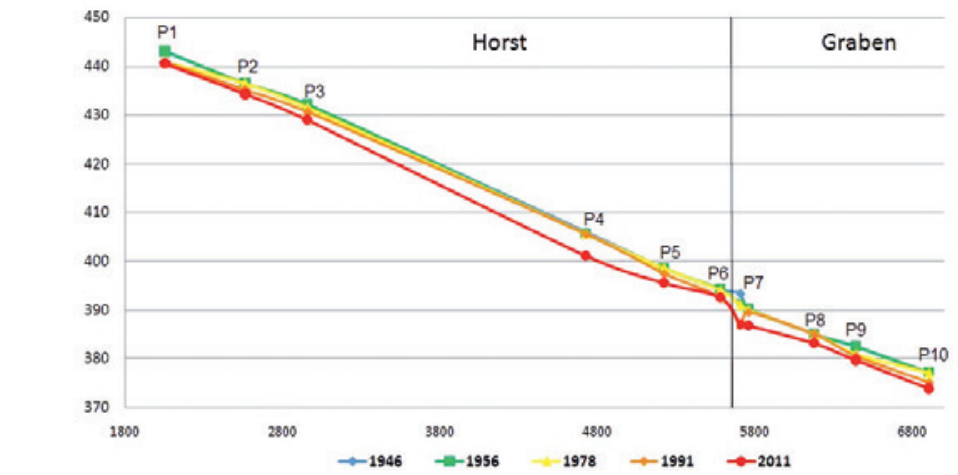

Figure 6. Changes in the longitudinal profile according to the incision estimated in the study area.

Regarding the temporal variability, incision between 1946 and 1956, was exclusively detected in two sections, P4 $(0.5 \mathrm{~m})$ and P7 $(2.4 \mathrm{~m})$. In the second period (1956-1977) was particularly relevant (between 1.5 and $2 \mathrm{~m}$ ) in P1 and P10, and moved to the points P2 $(1.29 \mathrm{~m}), \mathrm{P} 6(1.51 \mathrm{~m})$ and P11 $(2 \mathrm{~m})$ during the third period. Between 1991 and 2006 the maximum values were P4 (4.5 m), P5 (2 m) and P8 (2.6 m). Thus, there is a significant spatio-temporal variability, with maximums moving upstream and downstream between the different periods. This behavior is determined by natural factors, but also by the development of the gravel mining activity. Moreover, the marked spatio-temporal variability is probably indicating that the river adjustments have not finished and the equilibrium profile is far from being reached. Other authors have detected long periods of adjustment after intense gravel mining impacts in Mediterranean rivers (Rovira et al., 2005).

\subsection{Spatial variability of changes in channel width}

The channel width has undergone a progressive reduction through time, from the first available measurements in 1946 until 2006. During this period, the mean width of the study reach decreased from 214.6 to $67.6 \mathrm{~m}$. The most important reduction $(45.7 \%)$ took place between 1946 and 1956. This trend was interrupted in the period 1956-1977, when the channel width slightly increased by 2.9\%. Between 1977 and 1991, width channel decreased by $39.8 \%$, and in the last period there was a small width loss of $5.8 \%$.

The channel width reduction has not been uniform. During the period 1946-2006, the mean width reduction was $62.3 \%$ in the horst sector and $70.2 \%$ in the graben sector (Fig. 7). The major decrease took place in the graben sector between 1946 and 1956, when the channel lost $51.6 \%$ width, doubling the horst losses $(25.7 \%)$. During the period 1956-1977 both sectors followed different trends, increasing width in the graben sector (10\%), but decreasing in the horst area (15.5\%). Subsequently, both sectors decreased, markedly between 1977 and 1991 (34.4\% in the horst and $41.5 \%$ in the graben) and smoothly after 1991 (7.3\% in the horst and $5.1 \%$ in the graben). 
The spatial variability of the channel width changes is particularly relevant. Fig. $7 \mathrm{~B}$ shows a dual behavior between horst and graben sectors. The horst area underwent a slow and almost constant decrease before 1991, reaching stability during the last period. However, the graben followed a more variable trend. The reduction of the periods 1946-1956 and 1977-1999 was balanced during the other two periods, particularly by the gains of the period 1956-1977.

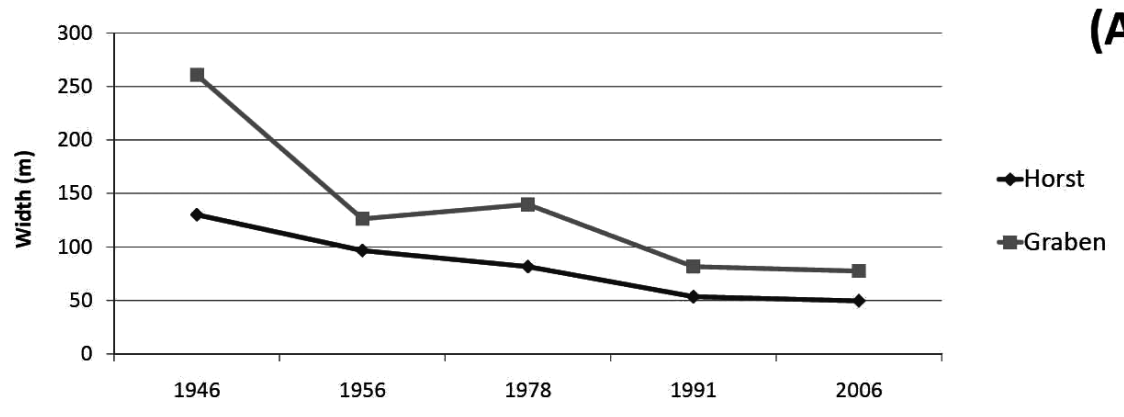

(A)

(B)

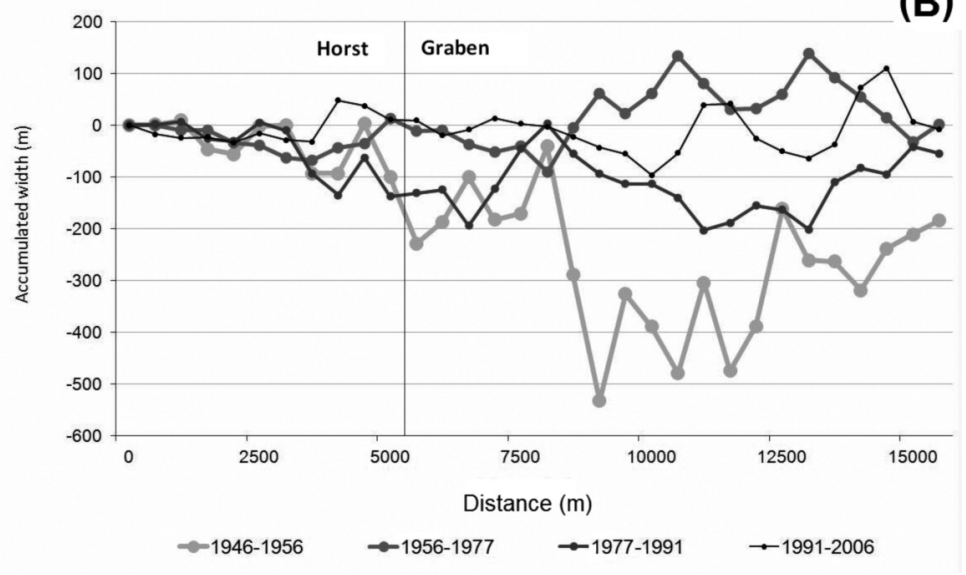

Figure 7. Changes in channel width: (A) Mean values of channel width in the horst and graben sectors; (B) Spatio-temporal distribution of accumulated width change.

The channel width is an extremely changing variable in braided rivers, frequently presenting a sequence of alternative wide and narrow sections. Consequently, the correlation between the initial channel width (1946) and the change of channel width in each period provide relevant information about the scope of channel width changes (Fig. 8). Between 1946 and 1956, there is a direct correlation between the initial width and the width reduction. The most significant reduction took place in the wider channel 
sections. In the three following periods, the correlation decreases, but it is possible to distinguish between two statistical populations, with a boundary width of $200 \mathrm{~m}$. This boundary separates the horst and graben areas, because only two sections of the horst are $>200 \mathrm{~m}$ and only 3 graben sections are $<200 \mathrm{~m}$. Fig. 8 also suggests that:

(i) the correlation of 1956-1977 data show a enlargement trend in sections $>200 \mathrm{~m}$ and a smooth reduction in sections $<200 \mathrm{~m}$.

(ii) the period 1977-1991 inverts this trend, presenting stabilization or smooth increase in sections $<200 \mathrm{~m}$ and severe decrease in sections $>200 \mathrm{~m}$.

(iii) the last period (1991-2006) has not a clear trend, but also presents two clear populations separated by the $200 \mathrm{~m}$ boundary.
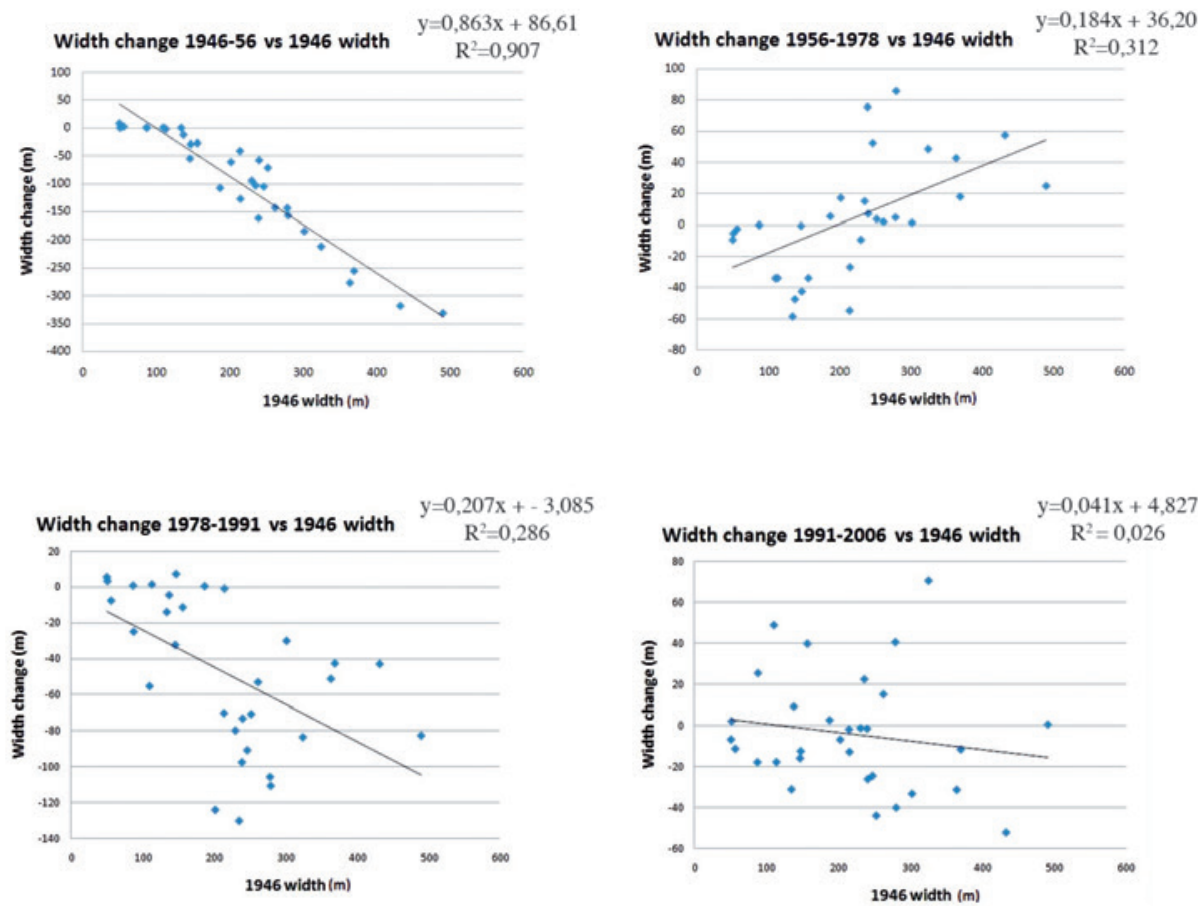

Figure 8. Correlation between the initial channel width (1946) and the change of channel width in each of the study periods.

These data suggest that, when the narrowing process affects the whole river, there is a direct and positive correlation between the initial width and the width reduction. However, when the river undergoes through mixed trends, the correlation is weaker. Thus, the 1956-1978 and 1991-2006 data show that the wider sections grow whereas the narrower are stable or decreasing. 


\subsection{Changes in river forms}

River forms have been substantially altered during the study period. The most significant change is the reduction of the gravel channel, which decreased in sixty years from 275 to 103 ha. Changes in river morphology followed this sequence in the study reach:

i) 1946-1956. The gravel channel underwent the major loss (97 ha). In this period, the gravel channel was occupied by incipient and established islands, whereas the floodplain surface slightly increased (Fig. 9).

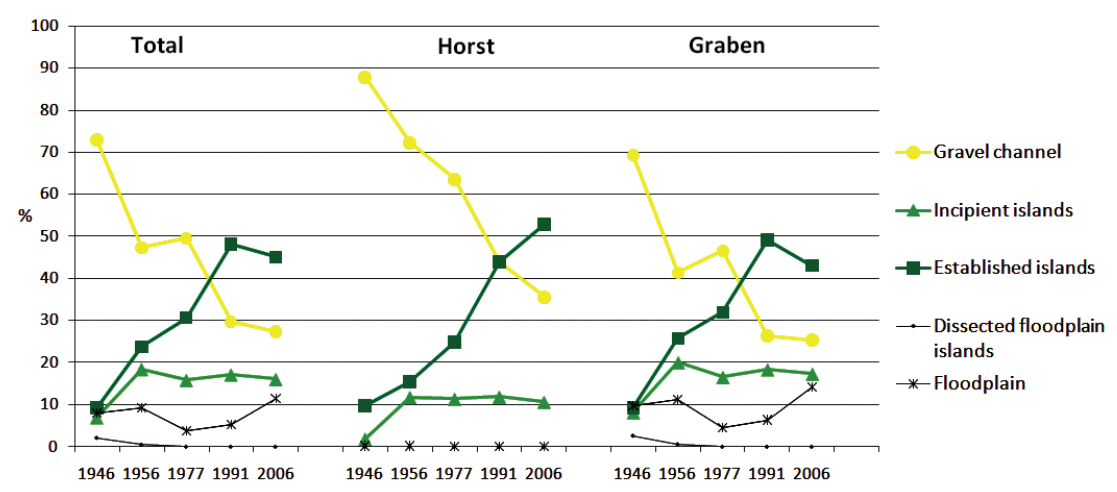

Figure 9. Compared evolution of channel forms in the horst and graben sections.

ii) 1956-1977. The gravel channel increased in 8.5 ha, whereas the incipient islands decrease in 9.7 ha and the established islands increase in 25.6 ha. This fact suggests that the widening trend of this period is materialized through the destruction of incipient islands, whereas the established islands are not affected by the river flow.

iii) 1978-1991. The gravel channel decreased again, losing 75 ha. Incipient islands slightly increased and established islands grew considerably (66 ha). Floodplain had a small growth (5.3 ha).

iv) 1991-2006. Floodplain increased significantly (24 ha), whereas islands decreased (3.8 ha in incipient islands and 11.4 ha in established islands).

The most commonly observed trend began when incipient islands were formed in some gravel patches covered by grass and scattered bushes. Further accumulation and growth of vegetation, woody debris, and sediment around these incipient islands supported their enlargement and coalescence, culminating in the formation of larger established islands. In some cases, early occupation by crops helped to fix the established islands. These trajectories reflect floodplain construction processes, through the progressive reduction of the gravel channel by the lateral growth and the relative elevation of islands. 
Incipient islands acted as a transitional stage and, for this reason, their surface is quite stable along the whole study period (Fig. 9 and Table 6). Only in 1946 are underrepresented, because of the impact of the recent flood of 1945, which covered most of the fluvial forms with a layer of cobbles. This is also one of the reasons which explains the important gravel channel change in the period 1946-1956, consolidated by a prolonged dry period (1946-1962) that fostered vegetation recovery and islands development.

Table 6. Surface of the corridor forms in the Rambla de Cervera study reach (1946-2006). Horst and graben sectors.

\begin{tabular}{|c|c|c|c|c|c|c|c|c|c|c|c|c|c|c|c|}
\hline & \multicolumn{3}{|c|}{1946} & \multicolumn{3}{|c|}{1956} & \multicolumn{3}{|c|}{1978} & \multicolumn{3}{|c|}{1991} & \multicolumn{3}{|c|}{2006} \\
\hline & Total & Horst & Graben & Total & Horst & Graben & Total & Horst & Graben & Total & Horst & Graben & Total & Horst & Graben \\
\hline Gravel channel & 72.9 & 87.9 & 69.3 & 47.2 & 72.2 & 41.3 & 49.5 & 63.5 & 46.5 & 29.6 & 43.8 & 26.2 & 27.2 & 35.5 & 25.2 \\
\hline Incipient islands & 6.9 & 1.8 & 8.1 & 18.4 & 11.7 & 20 & 15.8 & 11.3 & 16.5 & 17.1 & 11.8 & 18.3 & 16 & 10.6 & 17.3 \\
\hline Consolidated islands & 9.3 & 9.8 & 9.2 & 23.7 & 15.5 & 25.7 & 30.6 & 24.8 & 31.9 & 48 & 43.9 & 49 & 45 & 52.8 & 43 \\
\hline $\begin{array}{l}\text { Dissected floodplain } \\
\text { islands }\end{array}$ & 2.1 & 0 & 2.6 & 0.5 & 0 & 0.6 & 0 & 0 & 0 & 0 & 0 & 0 & 0 & 0 & 0 \\
\hline Floodplain & 7.9 & 0.1 & 9.7 & 9.1 & 0.1 & 11.2 & 3.7 & 0 & 4.5 & 5.1 & 0 & 6.3 & 11.4 & 0 & 14.1 \\
\hline Bare rock & 0.1 & 0.4 & 0 & 0.1 & 0.4 & 0 & 0.1 & 0.4 & 0 & 0.1 & 0.4 & 0 & 0.1 & 0.4 & 0 \\
\hline Chute channels & 0.9 & 0 & 1.1 & 1 & 0 & 1.3 & 0.4 & 0 & 0.5 & 0.1 & 0 & 0.2 & 0.4 & 0.7 & 0.3 \\
\hline
\end{tabular}

In many occasions, the stabilization of the established islands is a consequence of agricultural colonization processes. Farmers fix the islands with woody crops and drystone walls, usually perpendicular to flow direction. After the floods, if the flow has covered the fields, farmers restore their plots consolidating natural processes. This is a common phenomenon in Mediterranean ephemeral streams, particularly intense in this study area due to: a) the pressure on agricultural land in the decades of 1940, 1950 and early 1960s; b) the low perception and assessment of flood hazard, exacerbated during the prolonged dry periods such as 1946-1962.

Reverse (destructive) processes have also been found locally. In some areas and periods, islands destruction is produced as a consequence of channel gravel enlargement or divergence. Established islands are partially eroded and transformed into incipient islands, which in turn can become channels because of lateral shift, losing vegetation. However, complete floodplain dissection through chute channels has only been documented once (Fig. 10). The flood of 1945, which took place in a not incised river conditions, was the only event capable of causing floodplain dissection in the whole study period. This destructive process was subsequently reversed. In general terms, although these reverse trajectories are not spatially relevant, they result significant, because they prove the capacity of this ephemeral stream to temporally reverse trends and boost self-regeneration processes. 

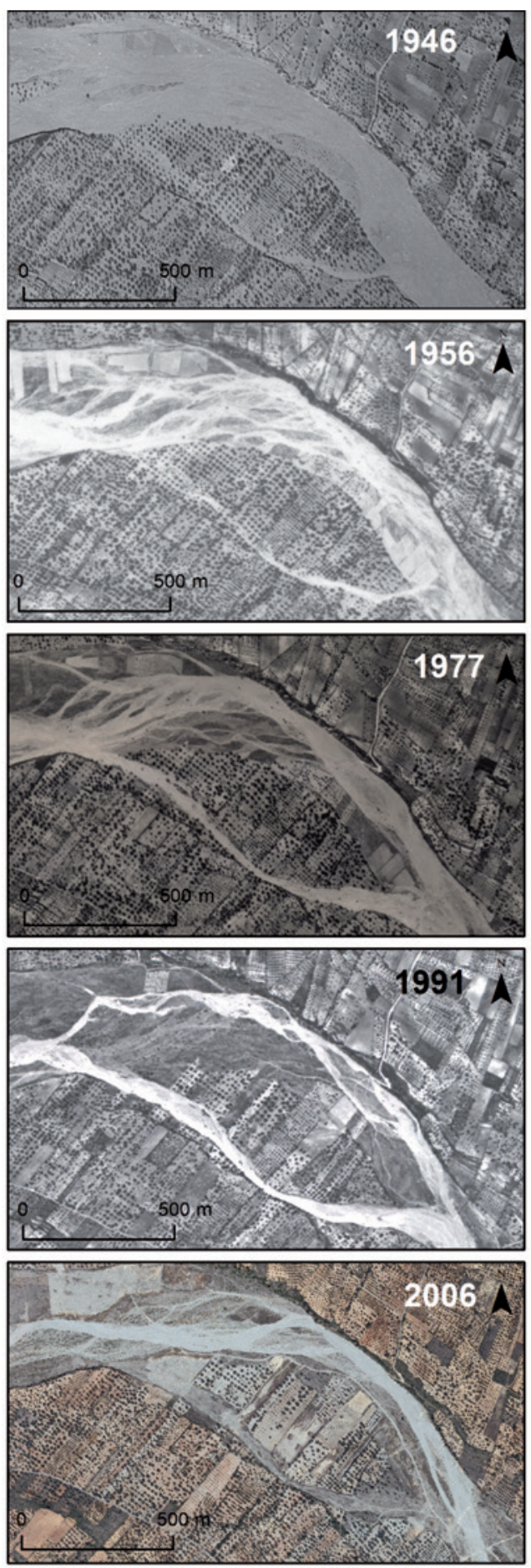

Figure 10. Evolution of a floodplain dissected island in the graben sector. A chute-channel dissected part of the floodplain during the flood of 1945. Subsequent events in the period 1956-1957 consolidated this channel form. Incision processes induced by gravel mining in the main gravel channel left the chute-channel lifted and, after the flood of 2000, it has been inactive. After 2006, part of the old channel has been planted with new olive groves. 
During the study period, the scope of these morphological changes differs in the two sections of the study area (Fig. 9):

- During the whole study period, changes are more sustained and gradual in the horst area, whereas in the graben sector important oscillations take place.

- Graben changes condition the evolution of the total study reach, because of the larger size of this sector. Thus, important changes in the graben forms, such as the drastic reduction of the gravel channel in the period 1946-1956 or the subsequent recovery (1956-1977), are also reflected as general trends.

- Incipient islands are less significant in the horst sector, and they present also more stability.

- Floodplain is not relevant in the evolution of the horst sector; it remains almost unaltered through all the periods.

Therefore, horst and graben sectors present different morphological trends, which can be observed through a compared analysis. According to the observed trajectories, the turnovers between the different forms were classified as constructive or destructive. Surfaces were calculated for each category and the most significant values $(>4 \%)$ are shown in Fig. 11. Floodplain and island constructive processes predominate over the whole period, but four stages have been identified:

- 1946-1956. Floodplain constructive trajectory prevailed. The most notable processes were the turnover of the gravel channel in the incipient and established islands. Horst sector presents a considerable stability through all the period $(72 \%)$, significantly higher than the graben stability (40\%).

- 1956-1977. Period with a mixed evolution that nearly equals the constructive and destructive trends. The channel grew in the graben sector, mainly at the expense of established islands, whereas in the horst sector reverse trends were not significant and constructive forms prevailed.

- 1977-1991. Clearly constructive period. The channel evolved into incipient islands and these to established islands in both sectors. Stability mainly affected the established islands, which for the first time exceeded the gravel channel in the graben sector.

- 1991-2006. Period with mixed trends. In the graben sector destructive processes affected an important surface, but numerous incipient islands were transformed into established islands, and these were attached to the floodplain. In the horst sector constructive processes prevailed again, and established islands stability exceeded the gravel channel.

In general terms, the constructive stages present similar values in both sectors, but the intensity of the morphological changes is always higher in the graben sector, particularly during the first stage (1946-1956). The horst sector is not affected by destructive processes, despite their significant impact on graben forms. The stability of horst forms is also more significant in all the periods, ranging between $83 \%$ and $69 \%$, whereas in the graben sector oscillates between $67 \%$ and $51 \%$. 
Horst

1946-1956

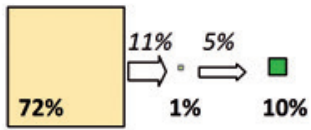

1956-1977

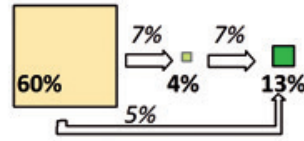

1977-1991

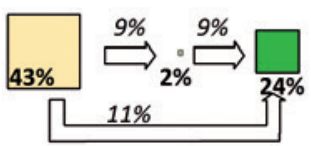

1991-2006
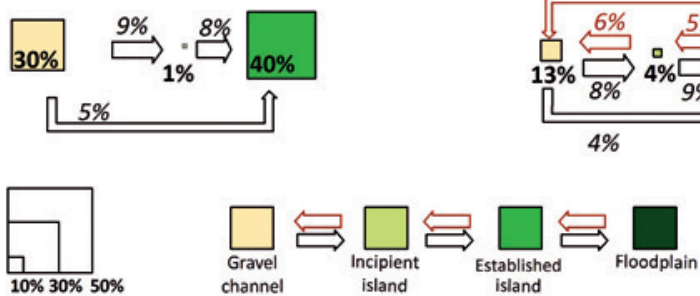

Figure 11. Evolutionary trends of corridor morphological units. The numbers express percentages ( $>4 \%$ ) of the surfaces moving from one category to another or remaining stable.

Floodplain constructive trajectories (arrows in black) reflect gravel channel evolving to incipient islands and these to established islands, reducing the gravel channel.

Regressive trends (in red) reflect floodplain destructive processes.

\section{Discussion}

\subsection{Conceptual model of evolution}

According to these results and to the natural and man-induced changes in basin and river conditions, we attempted to conceptualize the spatio-temporal variability of the channel changes in the Rambla de Cervera:

- 1946-1956. In the aerial photograph taken in the winter of 1946, the sediments from the recent flood (22/11/1945) cover former established islands, which had previously been occupied by agricultural plots. The river shows an aggradational pattern. However, in 1956, the river has undergone important changes in planform, with a differential behavior between the horst and graben sectors. The horst sector shows a moderated stability, whereas in the graben sector floodplain construction processes clearly predominate. The gravel channel decrease markedly and incipient and established islands grow. Incision 
is not relevant; it is only significant in the P7, immediately downstream the CV312 bridge. Several authors have documented similar changes in a context of natural hillslope reforestation (Liébault et al., 2005; Boix-Fayos et al., 2007; García-Ruiz and Lana-Renault, 2011; Preciso et al., 2012) and during prolonged dry periods (Rozin and Schick, 1996). These environmental changes took place in the Rambla de Cervera, where no significant flood events were registered between 1946 and 1962. The lack of rainfall events in the headwaters (Fig. 3) contributed to intensify the disconnection between the river basin and the river channel and to reduce the sediment supply. The absence of floods stimulated vegetation colonization of bars and islands, particularly intense in those sections wider than $200 \mathrm{~m}$, mainly placed at the graben sector (Fig. 8). The spatial variability of the hydraulic geometry explains the unequal distribution of the gravel channel reduction and the development of fluvial islands between the horst and graben sections. The scarce flow was more efficiently translated in the narrow sections, and lost erosional capacity in the wider ones. Thus, in the graben sector flow spreads, being affected by important transmission loses and reducing the effect of peak discharges over fluvial forms.

- 1956-1978. After 1962, the Rambla de Cervera underwent a decade with an important increase of flood events (1962, 1964, 1965, 1967 and 1971), which had a different impact in the graben and horst sectors. In the horst sector, the gravel channel reducing trend slightly slowed down, and the incipient islands moderately decreased (Fig. 9). In the graben sector, the action of recurrent large floods over a not incised channel facilitated the destruction of established islands and also the formation of a large dissected floodplain island (Fig. 10), causing an enlargement of the gravel cannel. These destructive processes related to the occurrence of high magnitude floods or to a high frequency of significant flow events have been documented in other Mediterranean rivers (Zanoni et al., 2008; Piégay et al., 2009; Rinaldi et al., 2009; Surian et al., 2009).

- 1978-1991. This stage presents trends very similar to the first period, with an important decrease of the gravel channel, increase of established islands and stability of fluvial forms. However, in this stage, there were two different, or even contrary, contextual factors. First, during these 14 years, three flood events were registered (1982, 1983 and 1988) and there was an important number of effective rainfall events. Second, the sediment deficit increased because of the impact of gravel mining, which also affected the hydraulic geometry of the river channel. These different driving factors lead to a similar behavior of the river forms, because of the influence of the hydraulic geometry. Channel incision, mainly induced by gravel mining since 1972, left the bars and the floodplain as a raised surface. Hence, the river flow could be concentrated in a major hydraulic radius, only causing sub-bankfull flow and reducing the impacts on the established islands. For this reason, the sequence of important floods was not capable of modifying the narrowing trend. Under these conditions, graben and horst sectors present very similar responses in this period, in terms of 
change and stability of fluvial forms. The only small difference is the slightly higher stability of the gravel channel in the horst sector (Fig. 11), consistent with the trend followed during the whole study period.

- 1991-2006. This period presents again a clear divergence between the horst and graben response to the common contextual factors. In the horst sector the gravel channel considerably decreases, increasing established islands. In the graben sector, the gravel channel remains stable, but in several places adopts a single channel form, because numerous established islands are attached to the floodplain. The horst sector shows a clear constructive trajectory, whereas the graben sector presents a mixed performance, with an increasing floodplain and important destructions of incipient and established islands. The dual behavior of graben and horst forms, which takes place under similar contextual factors (maximum of hillslope reforestation, decreasing gravel mining, decreasing rainfall events), was caused by the different impact of the extraordinary flood of October 2000. This large flood, which almost doubled in magnitude the rainfall registered in the rest of the flood events of the study period, was most likely responsible for the smooth growth and widening of the gravel channel in the graben sector (Table 3).

Therefore, during the whole study period, the horst sector presents higher stability and more constant trends, whereas the graben sector has a more irregular behavior, combining constructive and destructive or mixed stages, but following a similar general trend. Under similar basin environmental conditions, the single channel or wandering pattern of the horst sector shows a higher resilience to large events than the braided pattern of the graben sector. Large flows are transported by the horst sector without important impacts on river forms, whereas in the graben area, the higher mobility of the gravel channel affects a higher surface in the fluvial islands.

Thus, in this ephemeral stream, the visibility of the short-term reactions of the river planform to rainfall oscillations and floods recurrence is higher in the graben area, whereas the general trend of the fluvial adjustment, conditioned by the prolonged and continuous reduction of sediment supply in the whole basin, could be more properly identified in the horst sector.

\subsection{Driving factors of the variability of channel changes}

The different response of the graben and horst sectors to the common pattern of land use changes and hydroclimatic oscillations is explained by the local influence of the hydraulic conditions. Channel hydraulic configuration varies enormously between the graben and horst sectors. The graben section mean width doubles the horst section dimensions during the whole study period. The Rambla Cervera mean width was $110 \mathrm{~m}$ in horst and $258 \mathrm{~m}$ graben section in 1946, but $45 \mathrm{~m}$ in horst and $76 \mathrm{~m}$ in graben section in 2006. As a result of this, the Rambla de Cervera graben sector evolved from a clear braided pattern into the present wandering or simple channel.

The scope of the impact of rainfall and floods in this change in channel forms is also conditioned, in this study case, by the effective combination of the rainfall registered in the 
headwaters and study reach weather stations (Morella and Sant Mateu), because of the hydrographical configuration of the basin of the Rambla de Cervera. Soil moisture antecedent conditions, land use changes and soil properties, spatial and temporal variability in rainfall intensities (Camarasa-Belmonte and Segura-Beltrán, 2001), and transmission losses (Thornes, 1976; Shanon et al., 2002) result in high spatio-temporal variability of discharge and sediment supply. In this ephemeral stream, local rainfall events (registered only in one of the weather stations) have only a local effect and do not seem capable of causing significant adjustments in the channel planform (Table 3). Only the registered historical floods, result of the combination of important rainfall events in both headwaters and study reach sectors are capable of generating significant impacts in the river adjustment, with different rhythms in the horst and graben sectors of the river channel.

The timing of floods is also one of the key explanatory factors of the spatio-temporal variability of the recent morphological changes in the Rambla de Cervera. Adjustments are caused by limited and infrequent flow events and little changes take place in between events (Wolman and Gerson, 1978). Moreover, in ephemeral rivers recent works have shown that the influence of vegetation on river changes is strongly dependent on the variations of the temporal sequence of flood events (Hooke and Mant, 2002; Sandercock et al., 2007; Segura-Beltran and Sanchis-Ibor, 2013). These facts may contribute to produce adjustments with high spatio-temporal variability and higher asynchrony between causal factors and channel adjustments. The comparison of the graben and horst sectors have shown how, in this study case, the resilience of the channel forms of the horst sector to the timing and intensity of floods is considerably higher, whereas the river forms of the graben sector are more sensitive to this temporal variability.

Incision has played a major role in the adjustment of the river forms of this study reach. The transformation of incipient islands into established islands was boosted by incision processes, because of the relative and progressive elevation of the islands with regard to the gravel channel. The correlation of incision and changes in planform shows interesting results (Figs. 12 and 13). The increase of the established islands and the gravel channel decrease is well adjusted to the incision trends in the horst sector. They present, respectively, a positive and negative logarithmic adjustment, which ratifies the influence of incision in the evolution of these forms. In the graben sector the coefficient of correlation is significant, but not as high as in the horst sector. This fact is attributed to the higher impact of destructive changes in the braided sector during the larger flood events.

Other two factors must be considered to properly analyze the dual behavior between the graben and horst sectors. First, despite the poor information provided by the administration on gravel mining, photointerpretation shows that this activity was particularly intense in the graben sector. However, the scarce scope of the floodplain destructive processes in the 1977-1991 period, when this activity reached a maximum, proves the limited direct impact of gravel mining in channel planform changes in this study case. The evolution of the study reach proves that gravel mining has had a direct impact on incision processes, but the influence of this activity on the change of channel forms has been indirect, translated through the alteration of the hydraulic radius. 

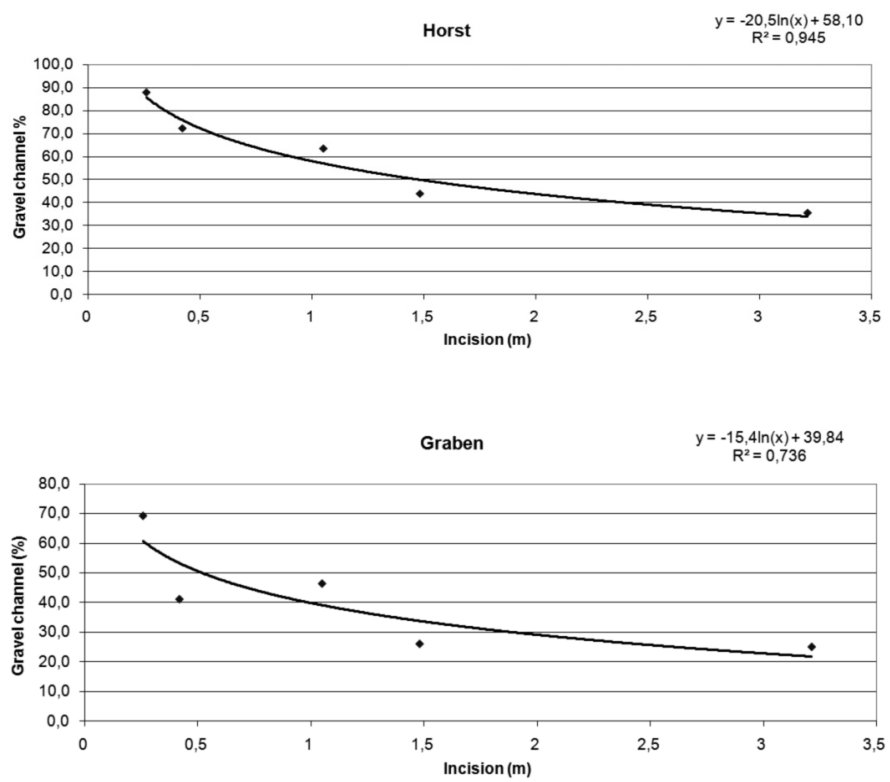

Figure 12. Correlation between gravel channel surface (\%) and incision in the horst and graben sectors.
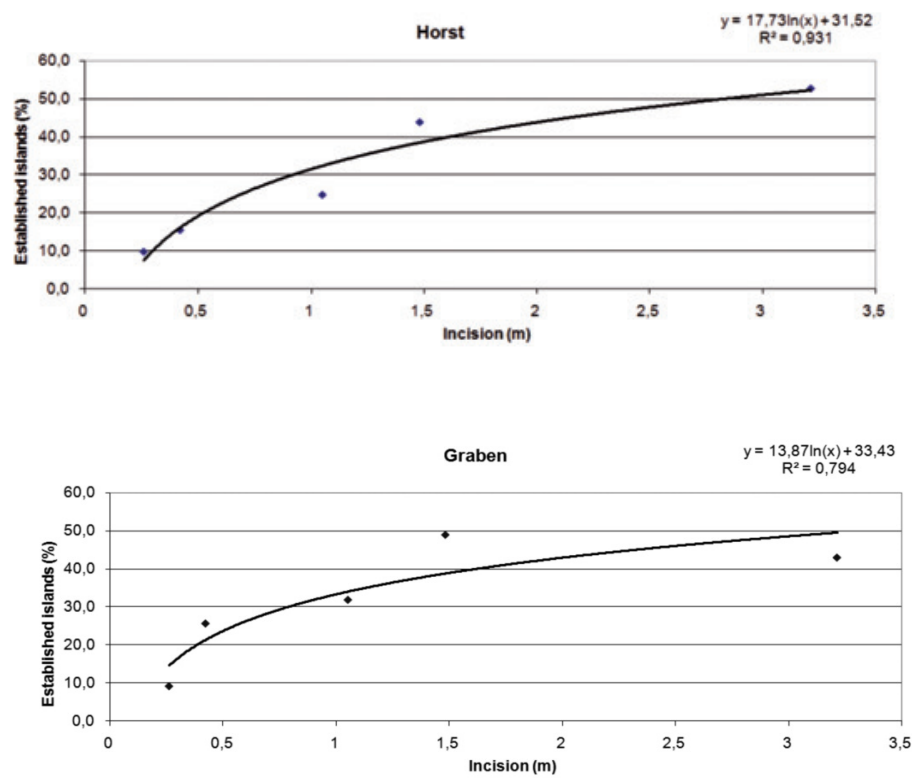

Figure 13. Correlation between consolidated islands surface (\%) and incision in the horst and graben sectors. 
Second, the distance to the sediment sources could have had a significant influence on the behavior of the graben sector. The exacerbated reduction of the gravel channel in the graben area and the formation of vegetated islands (particularly in the period 1946-1956) suggest that the lack of sediments is directly proportional to the distance to headwaters, usually considered as the main source of sediment supply.

\section{Conclusions}

Data analysis suggests that the decrease in sediment supply, caused by land use changes since 1946 and exacerbated by gravel mining since 1972, is the driving variable of narrowing and incision processes in the Rambla de Cervera. The absence of flow and the randomness of floods have determined the rhythm of these river adjustment processes, mainly through the active corridor vegetation encroachment. Despite the existence of a general narrowing and incision trend in the whole study area, the graben and horst sectors show a dual behavior during six decades. The horst sector underwent a constant and continuous trend, whereas changes in the graben sector were more intense, and went through two stages with significant reverse trajectories.

The differential behavior of the graben and horst sectors is caused by the different responses generated by the overlapping of three factors: the lack of sediment supply, the timing and intensity of flood events and the particular hydraulic conditions of both sectors. The hydraulic geometry of the different river sections conditions the effectiveness of flood events, influencing on the existence or absence of floodplain destructive trajectories and on the stability of fluvial forms.

These trends could continue in the future. Several works have predicted the behavior of some of the variables that are causing changes in the flow and sediment load of the Rambla de Cervera, and therefore, in the morphologic changes detected in the river channel. Future regional scenarios for different variables suggest an increased reduction on flow and sediments due to:

i) Decrease in rainfall as a result of the reduction of the convective and frontal rains (Millán et al., 2005).

ii) Expansion of forests and shrubs in the headwaters favors infiltration, evapotranspiration, and interception, while improves soil protection and reduces erosion (Gallart et al., 2011). This process is clearly in progress: in the horst area, a large proportion of land abandoned several decades ago is still in the primary stages of revegetation, covered by sparse shrub that should evolve into more developed stands of forest (García-Ruiz et al., 2011); in the graben area, land abandonment processes are progressing as a result of population aging.

iii) Gravel mining has decreased, but it is still legally practiced.

Finally, the different effectiveness of floods in the conditions previous and subsequent to the development of the gravel mining activity, proved in this study case, 
raises the question of the restoration of the Mediterranean ephemeral streams affected by intense gravel mining. Before 1972, without gravel mining and moderated hillslope reforestation, several floods were capable of having a significant destructive impact on the river forms. After 1977, a similar rainfall and floods pattern did not cause reverse trends, and only the extraordinary flood of 2000 -which took place when lack of sediment supply was higher- was capable of slowing down the constructive trends. This different behavior illustrates the limitations of the natural recovery of the braided pattern in a context of lack of sediment supply and persistent incision, and proves the difficulty to recover the original gravel channel width after the impact of gravel mining.

\section{References}

Arnaud-Fassetta, G. 2003. River channel changes in the Rhone Delta (France) since the end of the Little Ice Age: geomorphological adjustment to hydroclimatic change and natural resource management. Catena 51 (2), 141-172.

Barriendos, M., Rodrigo, F. S. 2006. Study of historical flood events on Spanish rivers using documentary data. Hydrological Sciences Journal 51 (5), 765-783.

Batalla Villanueva, R.J. 2003. Sediment deficit in rivers caused by dams and instream gravel mining: A review with examples from NE Spain. Cuaternario y Geomorfología 17 (3), 79 91.

Beguería, S., López-Moreno, J.I., Gómez-Villar, A., Rubio, V., Lana-Renault, N., García-Ruiz, J.M. 2006. Fluvial adjustments to soil erosion and plant cover changes in the Central Spanish Pyrenees. Geografiska Annaler, Series A-Physical Geography 88A (3), 177-186.

Benito, G., Thorndycraft, V.R., Rico, M., Sánchez-Moya, Y., Sopena, A. 2008. Palaeoflood and floodplain records from Spain: Evidence for long-term climate variability and environmental changes. Geomorphology 101 (1-2), 68-77.

Bertoldi, W., Gurnell, A., Surian, N., Tockner, K., Zanoni, L., Ziliani, L., Zolezzi, G. 2009. Understanding reference processes: linkages between river flows, sediment dynamics and vegetated landforms along the Tagliamento River, Italy. River Research and Applications 25 (5), 501-516.

Boix-Fayos, C., Barbera, G.G., López-Bermúdez, F., Castillo, V.M. 2007. Effects of check dams, reforestation and land-use changes on river channel morphology: Case study of the Rogativa catchment (Murcia, Spain). Geomorphology 91 (1-2), 103-123.

Bravard, J.P., Amoros, C., Pautou, G., Bornette, G., Bournaud, M., Creuzé des Châtelliers, M., Gibert, J., Peiry, J.L., Perrin, J.F., Tachet, H. 1997. River incision in southeast France: morphological phenomena and ecological effects. Regulated Rivers: Research and Management 13 (1), 75-90.

Cadol, D., Rathburn, S., Cooper, D. 2011. Aerial photographic analysis of channel narrowing and vegetation expansion in Canyon De Chelly National Monument, Arizona, USA, 1935-2004. River Research and Applications 27 (7), 841-856.

Camarasa-Belmonte, A.M., Segura-Beltrán, F. 2001. Flood events in Mediterranean ephemeral streams (ramblas) in Valencia region, Spain. Catena 45 (3), 229-249.

Gallart, F., Delgado, J., Beatson, S.J.V., Posner, H., Llorens, P., Marcé, R. 2011. Analysing the effect of global change on the historical trends of water resources in the headwaters of the Llobregat and Ter River basins (Catalonia, Spain). Physics and Chemistry of the Earth 36, 655-661.

García-Ruiz, J.M. 2010. The effects of land uses on soil erosion in Spain: A review. Catena 81 (1), 1-11. 
García-Ruiz, J. M., López-Moreno, J. I., Vicente-Serrano, S., Lasanta-Martínez, T., Beguería, S. 2011. Mediterranean water resources in a global change scenario. Earth-Science Reviews 105, 121-139.

García-Ruíz, J.M., Lana-Renault, N. 2011. Hydrological and erosive consequences of farmland abandonment in Europe, with special reference to the Mediterranean region - A review. Agriculture, Ecosystems and Environment 140, 317-338.

Glaser, R., Riemann, D., Schoenbein, J., Barriendos, M., Brazdil, R., Bertolin, C., Camuffo, D., Deutsch, M., Dobrovolny, P., van Engelen, A., Enzi, S., Halickova, M., Koenig, S.J., Kotyza, O., Limanowka, D., Mackova, J., Sghedoni, M., Martin, B., Himmelsbach, I. 2010. The variability of European floods since AD 1500. Climate Change 101 (1-2), 235-256.

Gurnell, A.M., Petts, G.E., Hannah, D.M., Smith, B.P.G., Edwards, P.J., Kollmann, J., Ward, J.V., Tockner, K. 2001. Riparian vegetation and island formation along the gravel-bed Fiume Tagliamento, Italy. Earth Surface Processes and Landforms 26 (1), 31-62.

Gurnell, A., Surian, N., Zanoni, L. 2009. Multi-thread river channels: a perspective on changing European alpine river systems. Aquatic Sciences-Research Across Boundaries 71 (3), 253 265.

Gurnell, A.M., Bertoldi, W., Corenblit, D. 2012. Changing river channels: The roles of hydrological processes, plants and pioneer fluvial landforms in humid temperate, mixed load, gravel bed rivers. Earth-Science Reviews 111 (1-2), 129-141.

Hooke, J.M., Mant, J. 2002. Morpho-dynamics of ephemeral streams. In Dryland Rivers: Hydrology and Geomorphology of Semi-arid Channels, L. Bull, M. Kirkby (eds.), John Wiley \& Sons, Chichester, UK, pp. 173-204.

Hooke, J.M. 2006. Human impacts on fluvial systems in the Mediterranean region. Geomorphology 79 (3-4), 311-335.

Kondolf, G., Piégay, H., Landon, N. 2002. Channel response to increased and decreased bedload supply from land use change: contrasts between two catchments. Geomorphology 45 (1-2), 35-51.

Liébault, F., Piégay, H. 2002. Causes of 20th century channel narrowing in mountain and piedmont rivers of southeastern France. Earth Surface Processes and Landforms 27 (4), 425-444.

Liébault, F., Gomez, B., Page, M., Marden, M., Peacock, D., Richard, D., Trotter, C. 2005. Landuse change, sediment production and channel response in upland regions. River Research and Applications 21 (7), 739-756.

López-Bermúdez, F., Conesa-García, C., Alonso-Sarria, F. 2002. Floods: magnitude and frequency in ephemeral streams of the Spanish Mediterranean region. In Hydrology and geomorphology in semi-arid channels, L. Bull, M. Kirkby (eds.), John Wiley and Sons, Chichester, pp. 329-350.

López-Moreno, J.I., Beguería, S., García-Ruiz, J.M. 2006. Trends in high flows in the central Spanish Pyrenees: response to climatic factors or to land use change? Hydrological Sciences Journal 51, 1039-1050.

Martín-Vide, J.P., Ferrer-Boix, C., Ollero, A. 2010. Incision due to gravel mining: Modeling a case study from the Gallego River, Spain. Geomorphology 117 (3-4), 261-271.

Michalková, M., Piégay, H., Kondolf, G.M., Greco, S.E. 2010. Lateral erosion of the Sacramento River, California (1942-1999), and responses of channel and floodplain lake to human influences. Earth Surface Processes and Landforms 36, 257-272.

Millán, M.M., Estrela, M.J., Miró, J. 2005. Rainfall components: variability and spatial distribution in a Mediterranean Area (Valencia Region). Journal of Climate 18 (14), 26822705. 
Mount, N.J., Louis, J., Teeuw, R.M., Zukowski, P.M., Stott, T., 2003. Estimation of error in bankfull width comparisons from temporally sequenced raw and corrected aerial photographs. Geomorphology 56, 65-77.

Pardo, J.E., 1991. La erosion antrópica en el litoral valenciano. Generalitat Valenciana. Conselleria d'Obres Públiques, Urbanisme i Transports, Valencia, $240 \mathrm{pp}$.

Piégay, H., Walling, D.E., Landon, N., He, Q., Liébault, F., Petiot, R. 2004. Contemporary changes in sediment yield in an alpine mountain basin due to afforestation (the upper Drôme in France). Catena 55 (2), 183-212.

Piégay, H., Alber, A., Slater, L., Bourdin, L. 2009. Census and typology of braided rivers in the French Alps. Aquatic Sciences-Research Across Boundaries 71 (3), 371-388.

Preciso, E., Salemi, E., Billi, P. 2012. Land use changes, torrent control works and sediment mining: effects on channel morphology and sediment flux, case study of the Reno River (Northern Italy). Hydrological Processes 26, 1134-1148.

Rinaldi, M. 2003. Recent channel adjustments in alluvial rivers of Tuscany, central Italy. Earth Surface Processes and Landforms 28 (6), 587-608.

Rinaldi, M., Wyżga, B., Surian, N. 2005. Sediment mining in alluvial channels: physical effects and management perspectives. River Research and Applications 21 (7), 805-828.

Rinaldi, M., Simoncini, C., Piégay, H. 2009. Scientific design strategy for promoting sustainable sediment management: the case of the Magra River (central-northern Italy). River Research and Applications 25 (5), 607-625.

Rozin, U., Schick, A.P. 1996. Land use change, conservation measures and stream channel response in the Mediterranean/semiarid transition zone: Nahal Hoga, southern coastal plain, Israel. Erosion and Sediment Yield: Global and Regional Perspectives, Proceedings of the Exeter Symposium, IAHS Publ. 236, pp. 427-444.

Rovira, A., Batalla, R., Sala, M. 2005. Response of a river sediment budget after historical gravel mining (the lower Tordera, NE Spain). River Research and Applications 21 (7), 829-847.

Sandercock, P.J., Hooke, J.M., Mant, J.M. 2007. Vegetation in dryland river channels and its interaction with fluvial processes. Progress in Physical Geography 31, 107-129.

Segura Beltrán, F. 1990. Las ramblas valencianas: algunos aspectos de hidrología, geomorfología y sedimentología. Universitat de València, Secció de Geografia, València, $229 \mathrm{pp}$.

Segura-Beltrán, F., Sanchis-Ibor, C. 2013. Assessment of channel changes in a Mediterranean ephemeral stream since the early twentieth century. The Rambla de Cervera, eastern Spain. Geomorphology 201, 199- 214.

Shanon, J., Richarson, R., Thornes, J. 2002. Modelling event-based fluxes in ephemeral streams. In Dryland Rivers: Hydrology and Geomorphology of Semi-arid Channels, L. Bull, M. Kirkby (eds.), John Wiley \& Sons, Chichester, UK, pp. 129-173.

Surian, N., Rinaldi, M. 2003. Morphological response to river engineering and management in alluvial channels in Italy. Geomorphology 50 (4), 307-326.

Surian, N., Cisotto, A. 2007. Channel adjustments, bedload transport and sediment sources in a gravel-bed river, Brenta River, Italy. Earth Surface Processes and Landforms 32 (11), 1641-1656.

Surian, N., Ziliani, L., Comiti, F., Lenzi, M.A., Mao, L. 2009. Channel adjustments and alteration of sediment fluxes in gravel-bed rivers of north-eastern Italy: potentials and limitations for channel recovery. River Research and Applications 25 (5), 551-567.

Thornes, J.B. 1976. Semi-arid Erosional Systems: Case Studies from Spain. London School of Economics and Political Science, London, UK, 79 pp. 
Wishart, D., Warburton, J., Bracken, L. 2008. Gravel extraction and planform change in a wandering gravel-bed river: The River Wear, Northern England. Geomorphology 94 (1-2), 131-152.

Wolman, H.G., Gerson, R. 1978. Relative scales of time and effectiveness of climate in watershed geomorphology. Earth Surface Processes and Landforms 3 (2), 189-208.

Zanoni, L., Gurnell, A., Drake, N., Surian, N. 2008. Island dynamics in a braided river from analysis of historical maps and air photographs. River Research and Applications 24 (8), 1141-1159. 